\title{
PROFIL DIARE BERDARAH DI BAGIAN ILMU KESEHATAN ANAK BLU.RSUP. PROF.DR.R.D. KANDOU MANADO PERIODE 2008-2011
}

\author{
${ }^{1}$ Rony Hakim \\ ${ }^{2}$ Jeanette I. Ch. Manoppo \\ ${ }^{2}$ Max F. J. Mantik
}

\author{
${ }^{1}$ Kandidat Skripsi Fakultas Kedokteran Universitas Sam Ratulangi Manado \\ ${ }^{2}$ Bagian Ilmu Kesehatan Anak Fakultas Kedokteran Universitas Sam Ratulangi \\ Email: paai_manado@yahoo.com
}

\begin{abstract}
Bloody diarrhea is a dangerous condition which is a common problem in children. In this kind of diarrhea, there is blood in liquid stools. Most bacterial infections are responsible for most cases of bloody diarrhea. This study is a descriptive - retrospective study. This study aimed to determine the profile of bloody diarrhea in Pediatrics Department at Prof Dr. R.D. Kandou Hospital from 2008 through 2011. The results showed that microbial infection was the most frequent cause of bloody diarrhea $(78.7 \%)$, followed by mixed infection of microbes and intestinal worms, or fungi (14.7\%), and intestinal worms (6.6\%). Conclusion: Microbial infection was the most frequent cause of bloody diarrhea in Pediatrics Department at Prof Dr. R.D. Kandou Hospital Manado from 2008 through 2011.
\end{abstract}

Keywords: bloody diarrhea, children, infection.

\begin{abstract}
Abstrak: Diare berdarah adalah terdapatnya darah dalam tinja cair, dan umumnya disebabkan oleh infeksi bakteri. Kondisi ini merupakan suatu keadaan berbahaya dan masih menjadi masalah umum pada anak-anak. Penelitian ini merupakan penelitian dekriptif-retrospektif. Tujuan penelitian ini untuk mengetahui profil diare berdarah di Bagian/SMF Ilmu Kesehatan Anak RSU Prof Dr.R.D. Kandou periode tahun 2008- 2011. Data hasil pemeriksaan menunjukkan positif bakteri sebanyak 48 kasus $(78,7 \%)$, positif bakteri dan cacing sebanyak lima kasus $(8,2 \%)$, positif cacing empat kasus $(6,6 \%)$, positif bakteri, cacing dan jamur sebanyak tiga kasus $(4,9 \%)$, dan positif bakteri dan jamur sebanyak satu kasus $(1,6 \%)$. Simpulan: Infeksi bakteri merupakan penyebab tersering dari diare berdarah di Bagian/SMF Ilmu Kesehatan Anak RSU Prof Dr.R.D. Kandou periode tahun 2008- 2011.
\end{abstract}

Kata kunci: Diare berdarah, pada anak-anak, infeksi.

Diare berdarah merupakan suatu keadaan berbahaya dengan terdapatnya darah dalam tinja yang cair. Darah tersebut dapat berasal dari sepanjang traktus gastrointestinal. ${ }^{1}$ Diare yang berdarah adalah masalah umum pada anak-anak. Sangat penting untuk membedakan diare berdarah dari penyebab lain pendarahan usus. Infeksi bakteri dan infestasi parasit yang ber-tanggung jawab untuk sebagian besar kasus diare berdarah. Alergi susu adalah penyebab sering di bayi muda. Penyakit inflamasi usus kronis (chronic inflammatory bowel disease) menjadi penyebab tersering pada anak-anak yang lebih tua. Penyebab pasti dapat diketahui dengan jelas setelah dilakukan anamnesis yang menyeluruh dan pemeriksaan fisik serta pemeriksaan penunjang/ laboratorium. $^{2}$

Organisasi kesehatan dunia (WHO) mendefinisikan diare sebagai kejadian buang air besar dengan konsistensi lebih cair dari biasanya, dengan frekuensi empat kali atau lebih selama satu hari atau lebih. Definisi ini lebih menekankan pada konsistensi tinja daripada frekuensinya. Jika 
frekuensi $\mathrm{BAB}$ meningkat namun konsistensi tinja padat, maka tidak disebut sebagai diare. Diare menyerang anak pada tahun-tahun pertama kehidupannya. Insidensi diare tertinggi pada anak di bawah usia dua tahun, dan akan menurun seiring bertambahnya usia. Diare merupakan masalah kesehatan terutama pada balita baik di tingkat global, regional maupun nasional. Pada tingkat global, diare menyebabkan $16 \%$ kematian, sedikit lebih rendah dibandingkan dengan pneumonia, sedangkan pada tingkat regional (negara berkembang), diare menyumbang sekitar 18\% kematian balita dari 3.070 juta balita. ${ }^{3}$

Penyakit diare masih merupakan masalah kesehatan masyarakat di negara berkembang seperti di Indonesia, karena morbiditas dan mortalitasnya yang masih tinggi. Survei morbiditas yang dilakukan oleh Subdit Diare, Departemen Kesehatan dari tahun $2000 \mathrm{~s} / \mathrm{d} 2010$ terlihat kecenderungan insidens naik. Pada tahun 2000 IR penyakit diare 301/ 1000 penduduk, tahun 2003 naik menjadi 374 /1000 penduduk, tahun 2006 naik menjadi $423 / 1000$ penduduk dan tahun 2010 menjadi 411/1000 penduduk. Kejadian Luar Biasa (KLB) diare juga masih sering terjadi, dengan CFR yang masih tinggi. Pada tahun 2008 terjadi KLB di 69 Kecamatan dengan jumlah kasus 8133 orang, kematian 239 orang (2,94\%). Tahun 2009 terjadi KLB di 24 Kecamatan dengan jumlah kasus 5.756 orang, dengan kematian 100 orang (CFR 1,74\%), sedangkan tahun 2010 terjadi KLB diare di 33 kecamatan dengan jumlah penderita 4204 dengan kematian 73 orang $(1,74 \%)^{3}$

Berdasarkan kenyataan diatas penulis terdorong untuk mengadakan penelitian tentang profil diare berdarah di bagian Ilmu Kesehatan Anak BLU.RSUP. Prof.Dr.R.D. Kandou Manado periode 2008-2011.

\section{METODE PENELITIAN}

\section{Jenis penelitian}

Penelitian yang bersifat deskriptifretrospektif.

\section{Tempat dan waktu penelitian}

Penelitian dilakukan di Bagian Ilmu Kesehatan Anak BLU. RSUP. Prof.Dr.R.D. Kandou Manado dalam rentang waktu November 2011 sampai Januari 2012.

\section{Populasi dan sampel penelitian}

\section{Populasi}

Seluruh anak yang dirawat dibagian ilmu kesehatan anak BLU Ilmu Kesehatan Anak RSUP. Prof Dr. R.D. Kandou Manado periode Januari 2008 sampai 2011.

\section{Sampel}

Semua anak dengan diagnosis diare berdarah yang berobat di Bagian Ilmu kesehatan Anak RSUP. Prof Dr. R.D. Kandou Manado periode Januari 2008 sampai Desember 2011.

\section{Instrumen Penelitian}

Pengumpulan data dilakukan dengan menggunakan instrumen penelitian seperti alat tulis-menulis, status penderita dan buku register di Instalasi Rawat Inap dan Poliklinik Ilmu Kesehatan Anak BLU. RSUP. Prof.Dr.R.D.Kandou Manado mulai dari Januari 2008- Desember 2011.

\section{Variabel Penelitian}

Variabel penelitian dalam bentuk tabel, diagram dan teks atau tulisan. Variabel penelitian yang dilakukan dikelompokkan menurut umur, jenis kelamin, derajat dehidrasi, status gizi dan feces mikroskopis.

\section{Cara Kerja}

Mengumpulkan data kasus secara retrospektif dari status penderita dan buku register di Bagian Ilmu Kesehatan Anak BLU. RSUP. Prof.Dr.R.D.Kandou Manado mulai dari Januari 2008- Desember 2011. 


\section{HASIL PENELITIAN}

Tabel 1. Distribusi pasien diare berdarah di bagian IKA BLU. RSUP. Prof. DR. R.D. KANDOU MANADO menurut tahun periode 2008-2011.

\begin{tabular}{ccc}
\hline Tahun & Frekuensi & Persen \\
\hline 2008 & 12 & 19,7 \\
2009 & 9 & 14,8 \\
2010 & 27 & 44,3 \\
2011 & 13 & 21,3 \\
Total & 61 & 100,0 \\
\hline
\end{tabular}

Tabel 2. Distribusi pasien diare berdarah di bagian IKA BLU.RSUP. Prof. DR. R.D. KANDOU MANADO menurut jenis kelamin periode 2008-2011.

\begin{tabular}{ccc}
\hline Jenis Kelamin & Frekuensi & Persen \\
\hline Laki-Laki & 37 & 60,7 \\
Perempuan & 24 & 39,3 \\
Total & 61 & 100,0 \\
\hline
\end{tabular}

Tabel 3. Distribusi pasien diare berdarah di bagian IKA BLU. RSUP. Prof. DR. R.D. KANDOU MANADO menurut golongan umur periode 2008-2011.

\begin{tabular}{ccc}
\hline Golongan Umur & Frekuensi & Persen \\
\hline $0-<1$ tahun & 22 & 36,1 \\
$1-<2$ tahun & 6 & 9,8 \\
$2-<3$ tahun & 10 & 16,4 \\
$3-<4$ tahun & 8 & 13,1 \\
$4-5$ tahun & 15 & 24,6 \\
Total & 61 & 100,0 \\
\hline
\end{tabular}

Tabel 4. Distribusi pasien diare berdarah di bagian IKA BLU. RSUP. PROF. DR. R.D. KANDOU MANADO menurut derajat dehidrasi periode 2008-2011.

\begin{tabular}{lcc}
\hline Derajat Dehidrasi & Frekuensi & Persen \\
\hline Ringan & 4 & 6,6 \\
Ringan-Sedang & 9 & 14,8 \\
Berat & 2 & 3,3 \\
Tanpa Dehidrasi & 46 & 75,4 \\
Total & 61 & 100,0 \\
\hline
\end{tabular}

Tabel 5. Distribusi pasien diare berdarah di bagian IKA BLU. RSUP. PROF. DR. R.D. KANDOU MANADO menurut status gizi periode 2008-2011.

\begin{tabular}{lcc}
\hline Status Gizi & Frekuensi & Persen \\
\hline Gizi Buruk & 6 & 9,8 \\
Gizi Kurang & 30 & 49,2 \\
Gizi Baik & 21 & 34,4 \\
Overweight & 3 & 4,9 \\
Obesitas & 1 & 1,6 \\
Total & 61 & 100,0 \\
\hline
\end{tabular}

Tabel 6. Distribusi pasien diare berdarah di bagian IKA BLU. RSUP. PROF. DR. R.D. KANDOU MANADO menurut hasil pemeriksaan mikroskopis feses periode 20082011.

\begin{tabular}{lcc}
\hline \multicolumn{1}{c}{ Hasil } & Frekuensi & Persen \\
\hline Bakteri & 48 & 78,7 \\
Cacing & 4 & 6,6 \\
Bakteri+T.Cacing & 5 & 8,2 \\
Bakteri+T.Cacing+Jamur & 3 & 4,9 \\
Bakteri+Jamur & 1 & 1,6 \\
Total & 61 & 100,0 \\
\hline
\end{tabular}

Tabel 7. Distribusi pasien diare berdarah di bagian IKA BLU. RSUP. PROF. DR. R.D. KANDOU MANADO menurut nilai hemoglobin periode 2008-2011.

\begin{tabular}{lcc}
\hline Hasil & Frekuensi & Persen \\
\hline$<$ Normal & 41 & 67,2 \\
Normal & 17 & 27,9 \\
> Normal & 3 & 4,9 \\
Total & 61 & 100,0 \\
\hline
\end{tabular}

Tabel 8. Distribusi pasien diare berdarah di bagian IKA BLU. RSUP. PROF. DR. R.D. KANDOU MANADO menurut nilai leukosit feses periode 2008-2011.

\begin{tabular}{lcc}
\hline \multicolumn{1}{c}{ Hasil } & Frekuensi & Persen \\
\hline 0-1/LPB & 10 & 16,4 \\
1-2/LPB & 12 & 19,7 \\
>2/LPB $(+)$ & 39 & 64,3 \\
Total & 61 & 100,0 \\
\hline
\end{tabular}


Tabel 9. Distribusi pasien diare berdarah di bagian IKA BLU. RSUP. PROF. DR. R.D. KANDOU MANADO menurut eritrosit pada pemeriksaan feses periode 2008-2011.

\begin{tabular}{ccc}
\hline \multicolumn{1}{c}{ Hasil } & Frekuensi & Persen \\
\hline $0-1 / \mathrm{LPB}$ & 6 & 9,8 \\
1-2/LPB $(+)$ & 15 & 25 \\
$>2 / \mathrm{LPB}(+)$ & 40 & 65,6 \\
Total & 61 & 100,0 \\
\hline
\end{tabular}

\section{BAHASAN}

Pada penelitian ini sampel penelitian adalah penderita baru yang berobat di Bagian Ilmu Kesehatan Anak RSU Prof. Dr.R.D.Kandou Manado yang terdiagnosa sebagai diare berdarah, mulai dari tahun 2008-2011 adalah berjumlah 61 kasus. Frekuensi kasus diare berdarah tiap tahunnya bervariasi, dimana angka kesakitan pasien dengan diare berdarah secara keseluruhan mulai dari tahun 2008-2009 mengalami penurunan, periode 2010 terjadi peningkatan, dan pada tahun 2011 kembali terjadi penurunan, dengan peerincian : pada tahun 2008 ditemukan kasus diare berdarah sebanyak 12 kasus kemudian ditahun 2009 sebanyak 9 kasus, tahun 2010 sebanyak 27 kasus, dan tahun 2011 sebanyak 13 kasus.

Berdasarkan Tabel 2 tentang distribusi pasien diare berdarah menurut jenis kelamin, terdapat lebih banyak pada laki-laki yaitu dengan 37 kasus pada pria dengan presentase $60,7 \%$ dan 24 kasus pada wanita dengan presentase 39,3\%. Sesuai dengan kepustakaan, jenis kelamin bukan merupakan faktor yang berpengaruh pada kejadian diare. Menurut penelitian yang dilakukan Wiku Adisasmito tentang faktor resiko diare pada bayi dan balita di Indonesia (systematic review) faktor risiko jenis kelamin terhadap diare menunjukkan hubungan yang kurang signifikan. Penyebab diare menurut faktor anak (usia, jenis kelamin,status gizi, ASI ekslusif, imunisasi,dll) dari beberapa aspek yang diteliti pada penelitian tersebut, status gizi memiliki faktor risiko yang paling signifikan dalam menyebabkan penyakit diare pada bayi dan balita, rendahnya status gizi pada bayi dan balita merupakan faktor risiko yang rentan untuk menyebabkan penyakit diare. ${ }^{4}$

Berdasarkan tabel 3 distribusi pasien menurut umur didapatkan data golongan umur satu bulan sampai kurang dari satu tahun dengan 22 kasus (36,1\%). Kemudian golongan umur empat sampai lima tahun dengan 15 kasus, setelah itu golongan umur dua sampai kurang dari tiga tahun dengan 10 kasus, golongan umur tiga sampai kurang dari empat tahun dengan 8 kasus, dan golongan umur satu sampai kurang dari dua tahun dengan enam kasus. Dapat dilihat bahwa golongan umur yang paling banyak menderita diare berdarah adalah golongan umur satu bulan sampai kurang dari satu tahun. Sebuah penelitian yang dilakukan Shintamurniwaty tentang faktor resiko diare pada balita, dari hasil penelitiannya menunjukkan bahwa jumlah balita pen-derita diare terbanyak pada kelompok umur enam sampai dua belas bulan. Pada kelompok umur enam sampai dua belas bulan biasanya balita sudah mendapat ma-kanan tambahan/pendamping dan menurut perkembangannya mulai dapat merangkak sehingga kontak langsung bisa saja terjadi, kontaminasi dari peralatan makan dan atau intoleransi makanan itu sendiri yang dapat menyebabkan tinginya risiko terkena diare. ${ }^{4}$ Masa perkembangan tercepat dalam kehidupan anak terjadi pada masa balita. Namun masa balita merupakan masa yang paling rentan terhadap penyakit. $^{5}$

Berdasarkan hasil pemeriksaan (Tabel 4) didapatkan data penderita diare berdarah tanpa dehidrasi adalah sebanyak 46 orang $(75,4 \%)$, derajat dehidrasi ringan empat orang $(6,6 \%)$, dehidrasi ringan-sedang sembilan orang $(14,8 \%)$ dan dehidrasi berat sebanyak dua orang (3,3\%). Data yang diperoleh dari penelitian ini didapatkan bahwa pasien diare berdarah terbanyak yaitu tanpa dehidrasi.

Tabel 5 menunjukkan bahwa didapatkan hasil pasien diare berdarah dengan status gizi kurang yang paling banyak dengan jumlah 30 orang (49,2\%). Pasien diare berdarah dengan status gizi baik se- 
banyak 21 orang $(34,4 \%)$, status gizi buruk enam orang (9,8\%), status gizi overweight sebanyak tiga orang $(4,9 \%)$, dan obesitas sebanyak satu $(1,6 \%)$. Dari tabel tersebut dapat dilihat bahwa nilai terbanyak pada anak dengan status gizi kurang. Menurut kepustakaan, status gizi dan diare memiliki hubungan, terutama diare dengan gizi buruk. Diare berdarah pada anak disebabkan oleh kurangnya efektifitas usus dalam mengabsorbsi nutrisi akibat dari kerusakan vili oleh mikroorganisme patogen. Pada gizi buruk, proses re-epitelisasi tersebut tidak maksimal karena tubuh mengalami defisiensi mikronutrien antara zinc. Zinc berperan dalam pertumbuhan sel dan fungsi kekebalan. Kekurangan zinc menyebabkan re-epitelisasi usus menjadi lambat, vili yang rusak digantikan oleh sel-sel muda yang belum berfungsi dengan baik, dan fungsi kekebalan usus berkurang. Vili yang muda tersebut tidak mampu untuk menyerap nutrisi yang dibutuhkan oleh tubuh sehingga status gizi anak menjadi buruk. Makanan yang tidak diabsorbsi akan menumpuk dirongga usus sehingga terjadi peningkatan isi lumen yang kemudian akan membentuk diare, dan menginfeksi usus diare dapat disertai dengan darah. ${ }^{6,7}$

Berdasarkan hasil pemeriksaan mikroskopis feses (Tabel 6) didapatkan data hasil pemeriksaan yang menunjukkan positif bakteri sebanyak 48 kasus $(78,7 \%)$, positif bakteri dan cacing sebanyak 5 kasus $(8,2 \%)$, positif Cacing empat kasus $(6,6 \%)$, po-sitif terdapat bakteri,cacing dan jamur sebanyak tiga kasus $(4,9 \%)$ dan positif terdapat bakteri dan jamur sebanyak satu kasus (1,6\%). Dari data yang diperoleh dapat disimpulkan bahwa diare berdarah periode 2008-2011 yang disebabkan infeksi bakteri adalah yang paling banyak.

Berdasarkan hasil pemeriksaan darah ditemukan nilai hemoglobin dibawah normal terdapat 41 kasus $(67,2 \%)$, nilai hemoglobin dalam batas normal sebanyak 17 kasus $(27,9 \%)$, dan jumlah hemoglobin diatas normal sebanyak tiga kasus ( 4,9\%). Nilai pasien terbanyak adalah pasien dengan nilai hemoglobin dibawah normal. Hal ini sesuai dengan kepustakaan yang mengatakan bahwa nilai hemoglobin pada diare berdarah akan berkurang karena terjadi anemia. ${ }^{8}$

Berdasarkan hasil pemeriksaan mikroskopis feses, ditemukan 0-1 leukosit/LPB pada pemeriksaan feses terdapat 10 kasus dengan presentase 16,4\%, ditemukan 1-2 leukosit/LPB sebanyak 12 kasus dengan presentase $19,7 \%$, dan ditemukan leukosit diatas normal atau positif terjadi infeksi (lebih dari 2 leukosit/LPB) sebanyak 39 kasus dengan presentase $64,3 \%$. Penemuan leukosit dinyatakan positif apabila ditemukan lebih dari 2 leukosit/LPB. Hal ini sejalan dengan hasil pemeriksaan feses dimana paling banyak didapatkan infeksi bakteri. Temuan leukosit dalam jumlah yang banyak (lebih dari 10/LPB) atau makrofag, mendukung diagnosis Shigella atau bakteri invasif lain. ${ }^{9}$

Berdasarkan hasil pemeriksaan mikroskopis feses, ditemukan 0-1 eritrosit/LPB pada pemeriksaan feses terdapat 6 kasus dengan presentase 9,8\%, ditemukan 1-2 eritrosit/LPB sebanyak 15 kasus dengan presentase $25 \%$, dan ditemukan eritrosit lebih dari 2 eritrosit/LPB sebanyak 40 kasus dengan presentase $65,6 \%$. Berdasarkan kepustakaan, penemuan eritrosit pada kultur feses, menandakan sebuah keadaan patologis, normalnya tidak ditemukan eritrosit dalam feses.

\section{SIMPULAN}

Kesimpulan yang dapat ditarik dari hasil penelitian ini adalah sebagai berikut :

1. Frekwensi diare berdarah yang bervariasi tiap tahunnya mulai dari tahun 2008-2011.

2. Jenis kelamin tidak mempengaruhi kejadian diare berdarah.

3. Diare berdarah sering terjadi pada balita umur satu bulan sampai kurang dari tahun

4. Diare berdarah jarang menimbulkan dehidrasi.

5. Diare berdarah mempengaruhi status gizi anak.

6. Anak dengan diare berdarah sering me- 
nunjukkan nilai hemoglobin yang rendah.

7. Penemuan lebih dari 2 leukosit/LPB dalam pe-meriksaan feses menandakan adanya infeksi saluran cerna.

8. Diare berdarah karena infeksi bakteri adalah yang paling banyak selama periode 2008-2011.

9. Penemuan eritrosit pada kultur feses, menandakan sebuah keadaan patologis, normalnya tidak ditemukan eritrosit dalam feses.

\section{SARAN}

1. Perlu ditingkatkan perawatan pada anak terutama usia kurang dari satu tahun.

2. Perlu ditingkatkan penyuluhan kepada masyarakat tentang diare berdarah dan gejala-gejala dini.

3. Perlu dilakukan penelitian lebih lanjut tentang pemeriksaan laboratorium diare berdarah.

\section{DAFTAR PUSTAKA}

1. Williams, Robert MD. Bloody Diarrhea [homepage on the Internet]. 2011 [cited 2011 Nov]. Available from: http://health.bettermedicine.com/article/bloo dy-diarrhea.
2. Thomas DW. Bloody diarrhea in children [homepage on the Internet]. Nodate [cited 2011 Nov]. Diunduh dari: http://www.ncbi. nlm.nih.gov/pubmed/2487818.

3. Depkes RI. Buletin Diare [homepage on the Internet]. 2010 [cited 2011 Nov]. Available from: http://www.depkes.go.id/downloads/ Buletin\%20Diare_Final\%281\%29.pdf.

4. Wiku Adisasmito. Makalah Kesehatan. Faktor Resiko Diare Pada Bayi dan Balita di Indonesia Vol.II. Depok: Universitas Indonesia; 2007; hal.1-10.

5. Budianti C. Diare berdarah dan berlendir [homepage on the Internet]. 2008 [cited 2011 Nov]. Available from: URL: http://www.library.usu.ac.id/download/fk/pe nydalam-umar4.pdf.FK UI 2008.

6. Shandhu BK. Practical guideline for the management of gastroenteritis in children. $\mathrm{J}$ Ped Gastroenterol Nutr. 2001;33:s36-9.

7. Labenthal E. Chronic Diarrhea in Children. New York: Raven Press, 1984; p.31-56.

8. Dharma $\mathbf{R}$, Immanuel $S$, Wirawan $R$. Penilaian Hasil Pemeriksaan Hematologi Rutin [homepage on the Internet]. 2008 [cited 2011 Nov]. Available from: http://www.kalbe.co.id/files/cdk/fils/10Penil aianHasilPemeriksaan.pdf

9. Depkes RI. Pedoman Tatalaksana Diare [homepage on the Internet]. Nodate [cited 2011 Des]. Available from: http://www. depkes.go.id/downloads/tata\%20laksana $\% 2$ 0diare/buku\%20panduan.pdf. 